\title{
TOPOLOGICAL REVERSIBLE MODEL OF THREE-PHASE FIVE-LIMB TRANSFORMER
}

\author{
ZIRKA S. E. \\ Professor of the Department of physics and technology of the National University of \\ Dnipro, Dnipro, Ukraine, e-mail: zirka@email.dp.ua; \\ MOROZ Y. I. \\ Ph.D., Associate professor of the Department of physics and technology of the National \\ University of Dnipro, Dnipro, Ukraine, e-mail: yuriy_moroz@i.ua; \\ ARTURI C. M. \\ Professor of the Department of electronics, information and bioengineering of the \\ Politechnico di Milano, Milan, Italy, e-mail: cesaremario.arturi@polimi.it; \\ ELOVAARA. J. \\ Ph.D., Fingrid Oyj, Helsinki, Finland, e-mail: jarmo.elovaara@fingrid.fi; \\ LAHTINEN M. \\ Ph.D., Fingrid Oyj, Helsinki, Finland, e-mail: matti.2.lahtinen@gmail.com.
}

Purpose. The paper continues the authors' studies devoted to transients in three-phase five-limb transformers. The main purpose of the work is to propose a method of evaluating model parameters, which cover transformer operations in saturation. This purpose is achieved by using the concept of the model reversibility.

Methodology. The method of obtaining model parameters employs magnetic transformer model and is based on the idea of the model reversibility. The solution is found by equating input reluctances seen from the terminals of the innermost and outermost windings to the reluctances of the corresponding windings on air.

Findings. The modeling of GIC events represented in the paper is the most accurate ever obtained for threephase, five-leg transformers. The model is validated by close agreement of the predicted values and waveforms of the phase currents and reactive power with those measured in tests performed on two 400 MVA transformers connected back-to-back and to a $400 \mathrm{kV}$ power network. The validity of the model was verified at 75 and $200 \mathrm{~A}$ dc currents in the transformer neutral. It is shown that the model is a reliable tool in evaluating inrush currents.

Originality. The originality and advantage of the method proposed is its ability to determine the model parameters without fitting to experimental data obtained in regimes with highly saturated core. The method ensures the reversibility of the three-winding transformer model that is its correct behavior regardless of which winding is energized.

Practical value. The practical value and significance of the paper is caused by the fact that the model proposed is a simple and reliable tool for power system studies. As a practically important example, time domain response of transformer subjected to geomagnetically induced currents (GIC) is analyzed and compared with results of a comprehensive field experiment.

\section{Keywords: five-limb transformer; topological model; reversible transient model; current waveforms; experimen- tal validation; geomagnetically-induced currents; transformer test; inrush currents.}

\section{INTRODUTION}

The paper continues our studies on transient modeling three-phase five-limb transformer started in [1]. Speaking generally, the structure of corresponding topological models has been sufficiently elaborated in [2] [4]. So, the main difficulties are related to choosing model parameters and their verification under abnormal conditions. As the core approaches saturation, an appreciable magnetic flux is closed outside the core. So, the model behavior becomes increasingly dependent on elements determining the off-core fluxes.

It was shown in [1] that accurate model of five-limb transformer, which covers regimes with highly saturated core, can be developed without resorting to a detailed tank representation. So, the main elements, which control the off-core fluxes, are linear reluctances of the magnetic transformer model or corresponding inductances of its electrical equivalent.

In the presence of reliable experimental data, these elements can be found by trial and error method, which can be time-consuming, requiring some practical skills or special accelerating techniques [4].

In this paper, we propose a method to determine the model parameters without its fitting to test data obtained in regimes with highly saturated core.

A suitable approach is to make the model reversible - that is, accurate in deep saturation, irrespective of which transformer winding is energized [5]. Reversible models for single-phase transformers were then also proposed in [6] and [7]. In this paper, the method in [5] is extended to five-limb, three-winding transformer. The model is verified by comparing its predictions with results of the GICimmunity test [8] carried out on two five-limb 400 MVA transformers connected back-to-back and to the Fingrid power network. The accurate model predictions in a wide range of dc currents in their neutrals demonstrate that the model is a reliable tool independent of the core saturation. As another limiting case, we show an adequate model behavior during inrush current events. 


\section{TOPOLOGICAL TRANSFORMER MODEL}

The model employed in the study was described in [1]. To make the paper self-contained it is shown in fig. 1 where $F_{1}, F_{2}$, and $F_{3}$ represent the sources of magnetomotive force (MMF) of the innermost, middle, and the outermost windings 1, 2, and 3 with number of turns $N_{1}, N_{2}$, and $N_{3}$ respectively. The innermost channel $0-1$ and the equivalent leakage channels $1-2$ and 2 - 3 are characterized by the linear reluctances $R_{01}, R_{12}$, and $R_{23}$ respectively. The negative (fictitious) reluctances $R_{\mathrm{p}}$ are added to match all three binary short-circuit inductances [3].

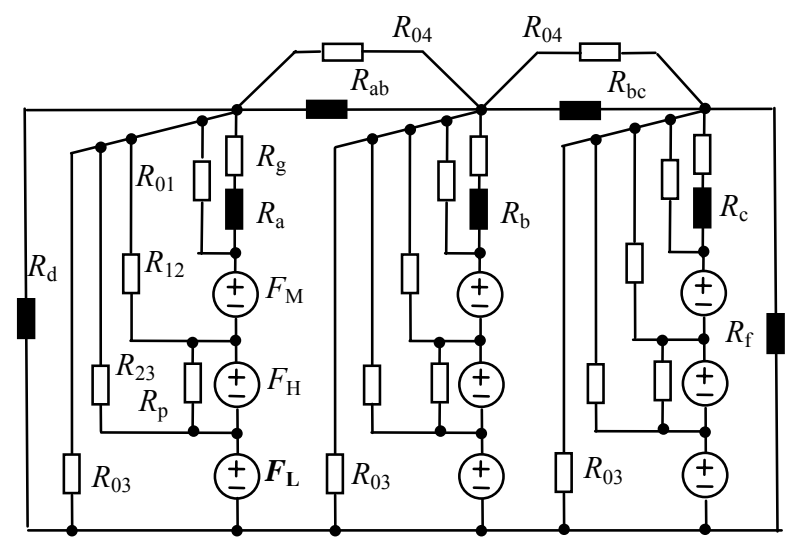

Figure 1.Magnetic circuit of five-limb, three-winding transformer.

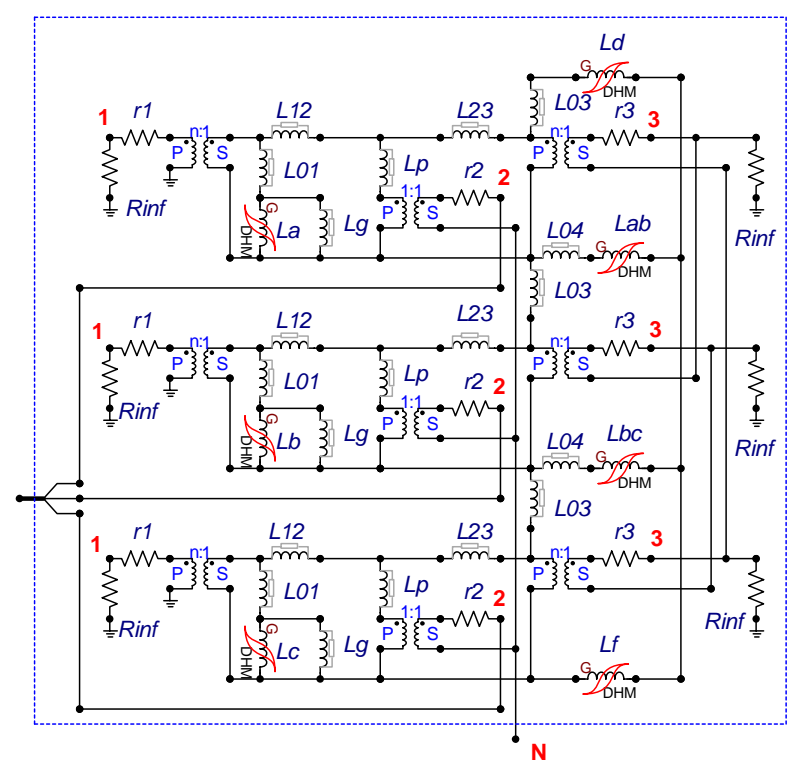

Figure 2. Electrical model of the three-winding five-limb transformer.

The winding resistances $\mathrm{r} 1, \mathrm{r} 2$, and $\mathrm{r} 3$ are brought outside the inductive part of the model. Resistances Rinf $=109 \Omega$ make the innermost windings 1 effectively open-circuited and the delta-connected windings 3 unloaded in accordance with [8].
To match the binary short-circuit inductances LS12, LS23, and LS13 measured in [8], the conventional starconnected inductances L12, L23, and Lp are used in the model of fig. 2. The negative value of $\mathrm{Lp}$ is found as $(\mathrm{LS} 12+\mathrm{LS} 23-\mathrm{LS} 13) / 2$ [1], then L12 $=\mathrm{LS} 12-\mathrm{Lp}$, and L23 $=$ LS23 - Lp. Going back to the magnetic circuit in fig. 1, we find its reluctances as $R_{12}=N_{2}^{2} / L_{12}$, $R_{23}=N_{2}^{2} / L_{23}$, and $R_{p}=N_{2}^{2} / L_{p}$.

In the derivation, we will also use the air-core inductances of the windings [8], calculated by the manufacturer in the absence of the core. Their values are provided in Section IV together with nameplate data of the transformer considered.

\section{OBTAINING REVERSIBLE MODEL}

The method of obtaining reversible model is to find its parameters so that the inductance of any single winding of the saturated core is equal to its air-core inductance $L^{\mathrm{air}}$. Consequently, the parameters of the magnetic model in fig. 1 should be chosen so that the input reluctance $R^{\text {in }}$ seen from the terminals of any MMF source associated with an $N$-turn winding is equal to the reluctance corresponding to the inductances of this winding on air, $R^{\text {air }}=N^{2} / L^{\text {air }}$, when the other windings are open, i.e. the corresponding MMF sources are short-circuited.

The reluctances of completely saturated legs $\left(R_{\mathrm{L}}\right)$, yokes $\left(R_{\mathrm{Y}}\right)$, and the end limbs $\left(R_{\mathrm{E}}\right)$ are calculated as $R=l /\left(\mu_{0} A\right)$ where $l$ and $A$ are their lengths and cross sections, and $\mu_{0}=4 \pi \cdot 10^{-7} \mathrm{H} / \mathrm{m}$. The core air gaps are included into the saturated legs, so we can accept that $R_{\mathrm{g}}=0$. Consequently, only four elements of the magnetic scheme in fig. 1 , namely $R_{01}, R_{03}, R_{03 \mathrm{~B}}$, and $R_{04}$, remain to be evaluated.

Accounting for the central symmetry of the fivelimb transformer, we can consider the windings of only two neighboring legs and thus write six equations of the type of $R^{\text {in }}=R^{\text {air }}$, so the problem is overdetermined. Significant facilitation of its solution in comparison to that in [9] is achieved when building the model reversible for two windings, innermost and outermost. This simplification is justified by the fact [10] that the winding inductances in air, and thus their binary short-circuit inductances are determined by the geometry and relative position of the actual coils. The reversibility of the model for the middle winding is then verified at the end of the derivation.

When building reversible model of two-winding transformer, we should remember that the windings of all three legs are identical. This allows us to divide the problem into two parts. The first one is finding reluctance $R_{01}$ of the innermost channel, and the second is the calculation of reluctances $R_{03}, R_{03 \mathrm{~B}}$, and $R_{04}$.

In the derivation, we take into account that the opening of a winding shorts the corresponding MMF source. This means that supplying the windings of only one of the 
legs (A, B or $\mathrm{C}$ ) and keeping the other transformer windings open, the scheme in fig. 1 is reduced to that in fig. 3(a). If, in addition, the middle winding 2 becomes opencircuited, the scheme is further simplified to that in fig. 3(b).

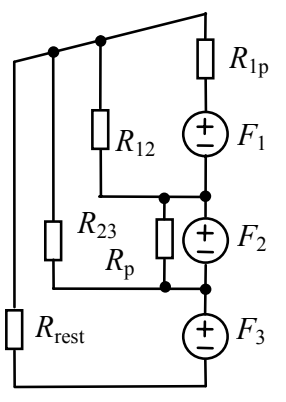

a)

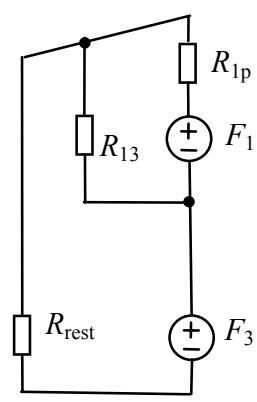

b)
Figure 3. Per phase equivalent models of (a) threewinding and (b) two-winding transformers.

Here $R_{1 \mathrm{p}}$ is the equivalent reluctance of the innermost channel merged with the saturated leg:

$$
R_{1 p}=\frac{R_{01} R_{L}}{R_{01}+R_{L}} .
$$

The leakage reluctance between the windings 1 and 3 is determined as

$$
R_{13}=\frac{R_{12} R_{23}}{R_{12}+R_{23}} .
$$

The element $R_{\text {rest }}$ represents the resultant reluctance of all magnetic paths outside the outermost winding of any leg. As the windings of all three legs are identical, the values of $R_{\text {rest }}$ and $R_{1 \mathrm{p}}$ are the same for all three legs. So, regardless of the leg (A or B), the scheme in fig. 3(b) has only two unknown parameters, $R_{\text {rest }}$ and $R_{1 \mathrm{p}}$. To find them, we can write relationships for two input reluctances, $R_{1}^{\text {in }}$ and $R_{3}^{\text {in }}$, seen from the MMF sources $F_{1}$ and $F_{3}$ in fig. 3(b). Then the imposed equalities $R_{3}^{\text {in }}=R_{3}^{\text {air }}$ and $R_{1}^{\text {in }}=R_{1}^{\text {air }}$ become two simultaneous equations for $R_{1 \mathrm{p}}$ and $R_{\text {rest }}$ :

$$
\begin{gathered}
R_{\text {rest }}+\frac{R_{13} R_{1 p}}{R_{13}+R_{1 p}}=R_{3}^{\text {air }}, \\
R_{l p}+\frac{R_{13} R_{\text {rest }}}{R_{13}+R_{\text {rest }}}=R_{l}^{\text {air }} .
\end{gathered}
$$

Expressing $R_{\text {rest }}$ from (3),

$$
R_{\text {rest }}=R_{3}^{\text {air }}-\frac{R_{13} R_{1 p}}{R_{13}+R_{1 p}}
$$

and inserting it in (4), we arrive to the quadratic equation for $R_{1 \mathrm{p}}$,

$$
\begin{gathered}
R_{1 p}^{2}+R_{1 p}\left(2 R_{13}-R_{1}^{\text {air }}\right)+ \\
+R_{13}\left(R_{13}-R_{I}^{\text {air }}-R_{13} \frac{R_{1}^{\text {air }}}{R_{3}^{\text {air }}}\right)=0
\end{gathered}
$$

whose bracketed coefficients are determined by the known "air" reluctances, which are independent of the structure of the transformer core.

The positive root of (6) is substituted back into (5) to give $R_{\text {rest }}$. Then, at given dimensions of the core (given $R_{\mathrm{L}}$ ), we find from (1) that:

$$
R_{01}=\frac{R_{1 p} R_{L}}{R_{L}-R_{1 p}} .
$$

Returning to the scheme in fig. 3(a), we can check the model reversibility for the middle winding. In its expanded form, condition $R_{2}^{\text {in }}=R_{2}^{\text {air }}$ becomes

$$
\left[\frac{1}{R_{p}}+\left(\frac{R_{1 p} R_{12}}{R_{1 p}+R_{12}}+\frac{R_{23} R_{\text {rest }}}{R_{23}+R_{\text {rest }}}\right)^{-1}\right]^{-1}=R_{2}^{\text {air }} .
$$

In the examples of Section IV, the error in fulfillment of (8) does not exceed $0.4 \%$. This is within the accuracy of the measurement (or calculation) of $R_{2}^{\text {air }}$ and corroborates the reversibility of three-winding model. The mentioned negligible error can also be viewed as model's ability to correctly predict the value of $R_{2}^{\text {air }}$, which was not used in the derivation.

Now we can return to the scheme in fig. 1 and determine reluctances $R_{03}, R_{03 \mathrm{~B}}$, and $R_{04}$. Since all the elements of the scheme in fig. 3, except $R_{\text {rest }}$, are present in each leg of fig. 1 , reluctance $R_{\text {rest }}$ can be calculated as the input reluctances $R_{\text {restA }}$ and $R_{\text {restB }}$ of the scheme seen from nodes $\mathrm{A}-\mathrm{A}^{\prime}$ and $\mathrm{B}-\mathrm{B}^{\prime}$ at shorted MMF sources in the rest of the scheme.

For nodes $\mathrm{A}-\mathrm{A}^{\prime}, R_{\text {rest }}$ is seen as:

$$
R_{\text {rest }}=R_{\text {restA }}=\left(\frac{1}{R_{E}}+\frac{1}{R_{03}}+\frac{1}{R_{A A}}\right)^{-1},
$$

and for nodes B-B' of the central leg,

$$
R_{\text {rest }}=R_{\text {rest } B}=\left(\frac{1}{R_{03 B}}+\frac{2}{R_{B B}}\right)^{-1} .
$$

Here reluctances $R_{\mathrm{BB}}$ and $R_{\mathrm{AA}}$ seen from the nodes A-A' and B-B', respectively, are expressed as:

$R_{B B}=R_{4 p}+\frac{R_{L p} R_{E}}{R_{L p}+R_{E}} ; R_{A A}=R_{4 p}+\frac{R_{L p B} R_{B B}}{R_{L p B}+R_{B B}}$,

where 


$$
\begin{gathered}
R_{L p B}=\left(\frac{1}{R_{03 B}}+\frac{1}{R_{13}}+\frac{1}{R_{1 p}}\right)^{-1} ; \\
R_{L p}=\left(\frac{1}{R_{03}}+\frac{1}{R_{13}}+\frac{1}{R_{1 p}}\right)^{-1}, \\
R_{4 p}=\frac{R_{04} R_{Y}}{R_{04}+R_{Y}} .
\end{gathered}
$$

With the above-found value of $R_{\text {rest }}$, relationships (9) and (10) are two simultaneous equations with three unknowns: $R_{03}, R_{03 \mathrm{~B}}$, and $R_{04}$. In virtue of the excessive number of variables, they can be found by minimizing function

$$
F(\boldsymbol{X})=\left[R_{\text {rest }}-R_{\text {restA }}(\boldsymbol{X})\right]^{2}+\left[R_{\text {rest }}-R_{\text {rest } B}(\boldsymbol{X})\right]^{2}(14)
$$

where $\mathbf{X}=\left[R_{03}, R_{03 \mathrm{~B}}, R_{04}\right]$ is a vector of sought variables. Since the order of $R_{\text {rest }}$ is $10^{5}$ and the found minimum of (14) is near $10^{-7}$, the iterative solution of (14) can be considered precise.

The peculiarity observed in minimizing (14) from different initial points is that $R_{04}$ does not practically leave its initial value. This means that for any fixed $R_{04}$ there is a pair of $R_{03}$ and $R_{03 \mathrm{~B}}$, which nullifies (14). This suggests to exclude $R_{04}$ from vector $\mathrm{X}$ and chose $R_{04}$ from physical considerations.

\section{PARAMETERS AND BEHAVIOR OF THE REVERSIBLE MODEL}

The results in this Section relate to YNyn0d11 400/400/125 MVA transformer described in [8]. Its wyeconnected $120-\mathrm{kV}$ windings are nearest to the core, the $410-\mathrm{kV}$ windings are in the middle, and the outermost are delta-connected $21-\mathrm{kV}$ windings. The numbers of turns $N_{1}, N_{2}$, and $N_{3}$ in these windings are 224, 766, and 68 . The air-core inductances of the windings are as follows: $L_{1}^{\text {air }}=24.9 \mathrm{mH}, L_{2}^{\text {air }}=496 \mathrm{mH}$, and $L_{3}^{\text {air }}=7.1 \mathrm{mH}$.

Model parameters. In accordance with the method in Section III, reluctances $R_{\mathrm{L}}, R_{\mathrm{Y}}$, and $R_{\mathrm{E}}$ of the saturated core are calculated using the lengths and cross sections given in [1].

The percentage short-circuit reactances provided in [8] yield the following binary short-circuit inductances referred to $N_{2}$ turns: $L_{\mathrm{S} 12}=263.5 \mathrm{mH}, L_{\mathrm{S} 23}=540.4 \mathrm{mH}$, and $L_{\mathrm{S} 13}=877.5 \mathrm{mH}$. These give the following inductances of the electrical model in fig. 2: $L_{12}=300.313 \mathrm{mH}$, $L_{23}=577.216 \mathrm{mH}$, and $L_{\mathrm{p}}=-36.787 \mathrm{mH}$.

To use the method in Section III, inductances $L_{12}$, $L_{23}, L_{\mathrm{p}}$, as well as three air-core inductances $L^{\text {air }}$ from [8], are recalculated into corresponding reluctances. Then using (6) and (5) we find that $R_{1 \mathrm{p}}=1.88810^{6} 1 / \mathrm{H}$ and $R_{\text {rest }}$ $=1.57510^{5} 1 / \mathrm{H}$. Now, it follows from (7) that $R_{01}=4.605$ $10^{6} 1 / \mathrm{H}$ and thus $L_{01}$ is $127.42 \mathrm{mH}$ or $0.095 \mathrm{pu}$.

Following [3], we can use the coefficient $K=$ $L_{01} / L_{\mathrm{S} 12}$ whereby $L_{01}$ is related to the inductance $L_{\mathrm{S} 12}$ of the nearest leakage channel 1-2. It is remarkable that the found value of $K(0.4835)$ is close to the value of 0.5 hard-coded in the hybrid transformer model [11].

To evaluate the influence of $R_{04}$, it is convenient to use the corresponding inductance, $L_{04}=N_{2}^{2} / R_{04}$. Three per-unit values of $L_{04}$ in Table I are for the cases when $L_{04}=L_{\mathrm{S} 12}(=0.197 \mathrm{pu})$; when $L_{04}$ is equal to the inductance of the saturated yoke $(0.064 \mathrm{pu})$, and when inductances $L_{04}$ are absent in the model of fig. 2. The components of vector $\mathbf{X}=\left[R_{03}, R_{03 \mathrm{~B}}\right]$, which nullify (14) for each $R_{04}$ (i.e. $L_{04}$ ), are represented in Table I by pu values of corresponding inductances.

The fact that $L_{03}$ and $L_{03 \mathrm{~B}}$ are by order of magnitude greater than $L_{\mathrm{S} 12}$ is explained by different "cross-sections" of the corresponding flux paths: the zero-sequence flux is distributed over the whole transformer volume, whereas the leakage flux is confined to the thin tube of the channel $1-2$.

Table 1. Parameters of Reversible Model

\begin{tabular}{|c|c|c|c|c|}
\hline $\begin{array}{c}L_{04} \\
{[\mathrm{pu}]}\end{array}$ & $\begin{array}{c}L_{03} \\
{[\mathrm{PU}]}\end{array}$ & $\begin{array}{c}L_{03 \mathrm{~B}} \\
{[\mathrm{pu}]}\end{array}$ & $\begin{array}{c}Q[\mathrm{Mvar}] \\
\left(I_{\mathrm{dc}}=200 \mathrm{~A}\right)\end{array}$ & $\begin{array}{c}Q[\mathrm{Mvar}] \\
\left(I_{\mathrm{dc}}=75 \mathrm{~A}\right)\end{array}$ \\
\hline 0.197 & 2.512 & 2.313 & 53.1 & 20.18 \\
\hline 0.056 & 2.639 & 2.566 & 53.9 & 20.27 \\
\hline 0 & 2.692 & 2.673 & 53.9 & 20.27 \\
\hline
\end{tabular}

Model verification under the GIC conditions. The electrical model in fig. 2 was verified by simulation of the experimental setup in [8] consisting of two $400 \mathrm{MVA}$ transformers ( $\mathrm{T} 1$ and $\mathrm{T} 2$ ) arranged in parallel relative to the power network and connected in series regarding the common de current in the transformers' neutrals. This model configuration and its parameters are shown in fig. 4 of [1].

It was assumed that the cores of these transformers are assembled from grain-oriented steel 27ZDKH85. The DHM-inductor of this steel can be taken at [12] or in the current version of EMTP-ATP [13].

To observe transformer dynamics in the presence of the geomagnetically-induced current (GIC), it is supposed that the biasing step voltage appears at $t=2 \mathrm{~s}$. The following transient is characterized by a growth in the reactive power $Q$ consumed by transformers and increasing winding currents as shown in fig. 4(a).

The model parameters in Table I were first used to check the model's ability to reproduce transformer behavior at maximum dc current in the neutrals $\left(I_{\mathrm{dc}}=200 \mathrm{~A}\right)$ reached in [8]. As the currents obtained are almost indistinguishable from those in [1], we do not show them in this paper. We only note that the reactive power $\mathrm{Q}_{2}$ consumed by transformer T2 at $I_{\mathrm{dc}}=200 \mathrm{~A}$ is close to 55 Mvar reported in [8].

In the context of the present study, it was important to verify the model at lower neutral current, say at $I_{\mathrm{dc}}=75$ A. The corresponding transient is illustrated by fig. 4(a), 
which shows the evolution of phase currents B and C of T2. The current waveforms in steady-state are given in fig. 4(b) to show their close agreement with the measured currents in fig. 5 recorded at $75 \mathrm{~A}$ dc current in the $\mathrm{HV}$ neutrals. The same agreement with test results was also obtained for the currents in the network as can be seen from comparing the waveforms in fig. 6(a) and fig. 6(b). The values of the reactive power $\mathrm{Q}_{2}$, given in the last column of Table I, are in a fairly good agreement with the linear dependence $Q_{2}\left(I_{\mathrm{dc}}\right)$ observed in [8].

The importance of these findings lies in the fact that the model parameters found for completely saturated core are also valid for modeling other transformer transients.
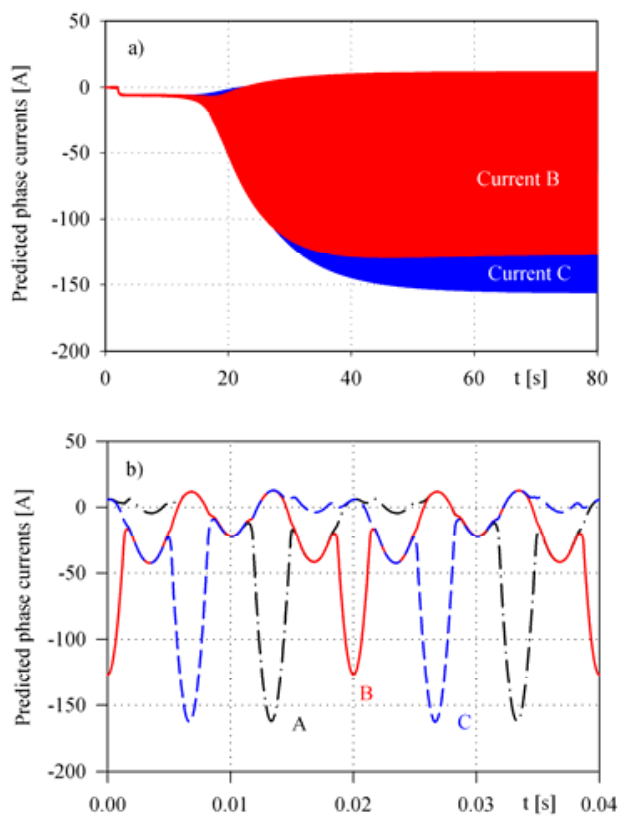

Figure 4. Predicted transient (a) and steady-state (b) phase currents of transformer T2 at the neutral GIC of 75 A.

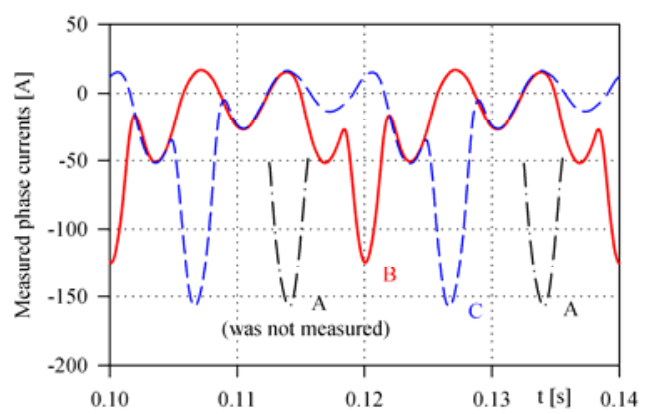

Figure 5. Measured phase currents $B$ and $C$ of transformer T2 at the neutral GIC of $75 \mathrm{~A}$. Note that current A was not measured and is assumed by analogy with that in fig. 4(b).

It should be noted that the model is not very sensitive to changes in its parameters if the model remains reversible. For example, the currents calculated for the model parameters in all three rows of Table I are not visibly different from those in fig. 4(b). As seen in the last columns of Table I, only a small difference is observed between the values of corresponding reactive power $Q_{2}$ consumed by $\mathrm{T} 2$.

It was found by numerical experiments that all the results calculated in the presence of GIC with nonhysteretic outlined in [1] and hysteretic model in fig. 2 almost coincide. This relates, for instance, to the current waveforms in fig. 4(b).
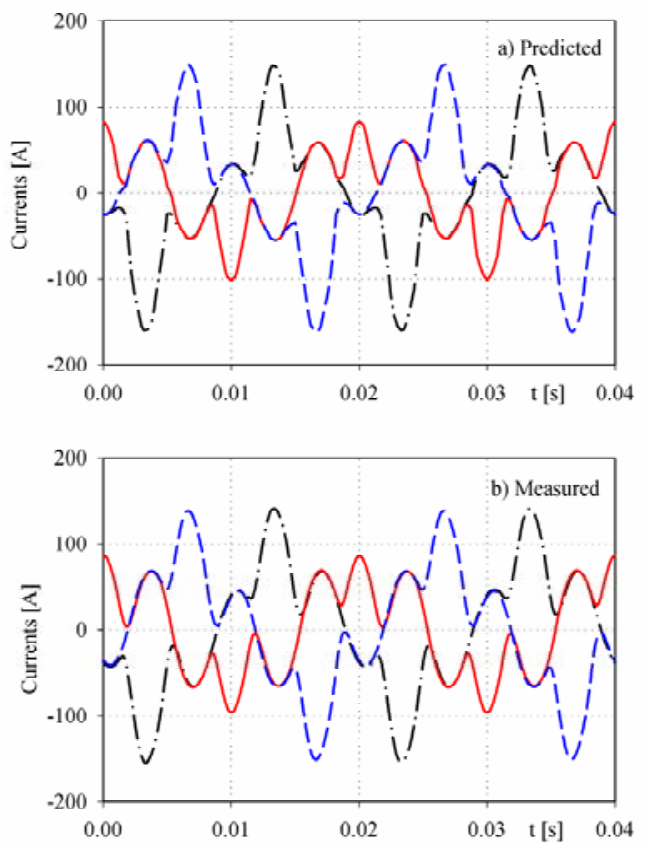

Figure 6. Predicted (a) and measured network currents at $\mathrm{I}_{\mathrm{dc}}=75 \mathrm{~A} \mathrm{(b)}$

Model verification by simulation of inrush currents. The hysteresis and non-hysteresis transformer models were also compared against each other in simulating inrush currents. To concentrate on the transformer only and compare the first (maximum) current peaks, we have assumed an idealized $(410-\mathrm{kV})$ power network and the worst condition of excitation, when the phase voltage $v(t)=V_{\mathrm{m}} \sin (\omega t)$ is switched (at $\left.t=0\right)$ to the winding $(N$ turns) of the leg with cross section $S_{\text {leg. }}$. Before exciting hysteresis transformer model, all the core sections were brought into the demagnetized state using an inbuilt procedure of the DHM.

The currents in fig. 7 are calculated by the transformer model in fig. 2 supposing that the sinusoidal voltage is applied to the high-voltage (HV) winding of phase A.

It was instructive to compare the height of the first current peak in fig. 7 with the value calculated analytically. For the case considered, i.e. for the zero initial induction in the leg and the idealized sinusoidal voltage 
source, the well-known formula (1) from [5] is rewritten as

$$
I_{m}=\frac{V_{m}}{\omega L_{\text {air }}}\left[2-\frac{\omega B_{S} N S_{\text {leg }}}{V_{m}}\right]
$$

where the saturation induction $B_{\mathrm{S}}$ of steel $27 \mathrm{ZDKH} 85$ is $2.00825 \mathrm{~T}$, and in accordance with the data above, $L_{\text {air }}=L_{2}^{\text {air }}=0.496 \mathrm{H}, N=N_{2}=766$, and $S_{\text {leg }}=0.8309 \mathrm{~m}^{2}$.

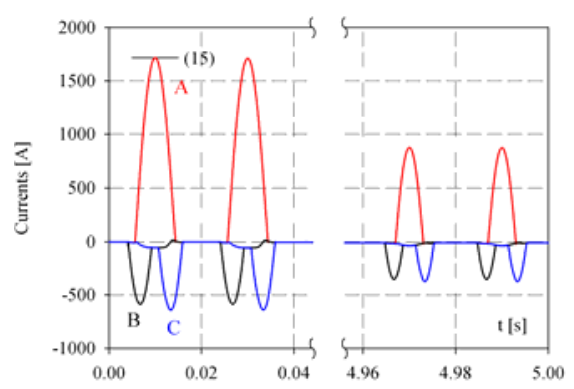

Figure 7. Predicted inrush currents in phases of the HV winding. The horizontal mark shows the current peak calculated with (15).

The value $I_{\mathrm{m}}=1719.7 \mathrm{~A}$, calculated with (15), is shown in fig. 7 by the horizontal line (15), which is at the same level with the current peaks calculated with hysteresis and non-hysteresis transformer models (1718.0 A and 1720.8 A respectively).

The same negligible difference between the current peak (10039.3 A) calculated with (15) and that predicted by the models (9987.5 A) takes place when the transformer is excited from its MV side, i.e. from the innermost windings. Finally, when the outermost delta winding of the model is opened, the calculated current peaks are decreased by $1.9 \%$ at the HV excitation, and by $0.05 \%$ at the MV energizations.

It worth noting that (15) is derived supposing a coil whose core material has piecewise linear $B-H$ curve with two slopes and the bending point at $B=B_{\mathrm{S}}$. The first segment of the curve is strictly vertical, while at $B>B_{\mathrm{S}}$ the coil's inductance becomes equal to $L_{\text {air }}$. This means that the slope of the second segment is equal to $\mu_{0}$.

The modeling above illustrates the model reversibility and corroborates the conclusion in [14] that the twoslope magnetizing curve can be used to evaluate inrush currents in large three-phase transformers. At the same time, it was noted in [14] that it is critical to identify the proper saturation level (knee point). It was pointed out in [5], however, that the notions of saturation and knee are somewhat ambiguous. For this reason, it is better to use the whole $B-H$ curve, which can be represented easily by several dozen points in the EMTP software. Such a universal representation is also preferable in predicting inrush currents accompanied by moderate saturation, when the flux density does not exceed 1.9-2.0 Tesla [14].
When using the non-hysteresis version of the model, the single-valued $B-H$ curve of the steel employed is converted into the flux-current curves of the core sections using the well-known relationships $\lambda=B \cdot N \cdot S$ and $i=l \cdot H / N$, where $S$ and $l$ are cross section and length of the section, and $N$ is the common number of turns at which the model is referred to (here $N=N_{2}$ ).

The users of ATP can employ DHM-inductors, in which the chosen steel, as well as $N, S$, and $l$ are set in the inductor window. It should be remembered that the hysteretic (DHM-based) transformer model retains the remanent flux densities in the core sections and is more accurate in predicting current peaks during subsequent transformer energizations. It can be also fitted so as to reproduce the measured no-load transformer losses in a wide range of terminal voltages [15].

\section{V.CONCLUSION}

This paper has proposed a method of obtaining a reversible topological model of five-limb, three winding transformer. A distinguishing feature of the method is its ability to determine the model parameters without fitting to experimental data obtained in conditions with highly saturated core. The validity of the obtained model was verified by simulating transformer behavior under GIC conditions. To do this, we have used parameters and field test results from two 400 MVA transformers at 75- and 200-A dc currents entering their neutrals.

We have observed that both hysteretic and nonhysteretic transformer models are equally suitable to reproduce the behavior of the five-limb transformer in the presence of GIC.

In the general-purpose modeling of five-limb transformers, the users of ATP may also employ the hysteretic version of the model. In this case, the dynamic hysteresis model (DHM) included in the current version of ATP [13] can be used.

In general, the model proposed does not require detailed information on the core, and the preliminary modeling was carried out using the core geometry different from the real one [1]. If the air core inductances of the windings are unknown and it is impossible to ensure the model reversibility, the linear inductances $L_{03}$ and $L_{03 \mathrm{~B}}$ in the model of fig. 2 may be set equal to 2-3 pu, as seen in Table 1, or $10-15$ times the short-circuit transformer inductance.

The hysteresis and non-hysteresis transformer models were also compared against each other in simulating inrush currents when model reversibility was verified by comparing current peaks on the $\mathrm{HV}$ and MV sides with accurate analytical predictions.

\section{REFERENCE}

[1] Zirka, S., Moroz, Y., Arturi, C., \& Bonnman, D. (2018). Topological transient models of three-phase five-limb transformer. Electrical Engineering And Power Engineering, 2, 18-25. 
doi:http://dx.doi.org/10.15588/1607-6761-2017-2-2

[2] Arturi, C. M. (1991). Transient simulation of a three phase five limb step-up transformer following an outof-phase synchronization. IEEE Trans. Power Delivery, $6, \quad 1, \quad 196-207 . \quad$ doi: http://dx.doi.org/10.1109/61.103738

[3] Chen, X., Venkata, S.S. (1997). A three-phase three winding core-type transformer model for low frequency transient studies. IEEE Trans. Power Delivery, 12, 2, 775-782. doi: http://dx.doi.org/0885$8977 / 97 / \$ 10.00$

[4] Walling, R. A., Khan, A. H. (1991). Characteristics of transformer exciting current during geomagnetic disturbances. IEEE Trans. Power Delivery, 6, 4, 1707 1714. doi: 0885-8977/91\$01.00

[5] Zirka, S. E., Moroz, Y. I., Arturi, C. M., Chiesa, N., Høidalen, H. K. (2012). Topology-correct reversible transformer model. IEEE Trans. Power Delivery, 27, 4 , 2037-2045. doi: http://dx.doi.org/10.1109/TPWRD.2012.2205275

[6] Jazebi, S., León, F. de, Farazmand, A., Deswal D. (2013). Dual reversible transformer model for the calculation of low-frequency transients. IEEE Trans. Power Delivery, 28, 4, 2509-2516. doi:http://dx.doi.org/10.1109/TPWRD.2013.2268857

[7] Jazebi, S., León, F. de. (2015). Experimentally validated reversible singe-phase multiwinding transformer model for the accurate calculation of lowfrequency transients. IEEE Trans. Power Delivery, 30 ,

1 , 193-201. doi:http://dx.doi.org/10.1109/TPWRD.2014.2319093

[8] Lahtinen, M., Elovaara, J. (2002). GIC occurrences and GIC test for $400 \mathrm{kV}$ system transformer. IEEE Trans. Power Delivery, 17, 2, 555-561. doi:http://dx.doi.org/0885-8977(02)02750-4.
[9] Yang, M., Kazemi, R., Jazebi, S., D. Deswal, Leon, F. De. (2018). Retrofitting the BCTRAN transformer model with non-linear magnetizing branches for the accurate study of low-frequency deep saturating transients. IEEE Trans. Power Delivery, 5, 33, 23442353.

doi:http://dx.doi.org/10.1109/TPWRD.2018.2825252

[10]Alexander Ch., Sadiku M., (2013). Fundamentals of electric circuits, $5^{\text {th }}$ edition. New York, NY, USA: McGraw-Hill.

[11]Høidalen, H. K., Mork, B. A., Gonzalez, F., Ishchenko, D., Chiesa, N. (2009). Implementation and verification of the hybrid transformer model in ATPDraw, Electric Power Systems Research, 79, 3, 454-459.

http://dx.doi.org/10.1016/j.epsr.2008.09.003

[12]Moroz, Y. I., Zirka, S. E. (2014). Inverse models of magnetic hysteresis, [Online]. Available: https://sites.google.com/site/inverse-hysteresismodel.

[13]Alternative Transients Program, ATP-EMTP. (2016). [Online]. Available: http://www.eeug.org

[14]S. Jazebi, A. Rezaei-Zare, M. Lambert, et al. (2016). Duality-derived transformer models for lowfrequency electromagnetic transients-Part II: Complementary modeling guidelines. IEEE Trans. Power Delivery, 31, 5, 2420-2430. doi: http://dx.doi.org/10.1109/TPWRD.2016.2556686

[15]Zirka, S. E., Moroz, Y. I., Høidalen, H. K., Lotfi, A., Chiesa, N., Arturi, C. M. (2017). Practical experience in using a topological model of a core-type threephase transformer - no-load and inrush conditions. IEEE Trans. Power Delivery, 32, 4, 2081-2090. doi:http://dx.doi.org/10.1109/TPWRD.2016.2618900

The article was received 02.06 .2018

\section{ТОПОЛОГІЧНА ОБОРОТНА МОДЕЛЬ ТРИФАЗНОГО П'ЯТИСТРИЖНЕВОГО ТРАНСФОРМАТОРА}

3IPKA C. E.

MOPO3 Ю. I.

АРТУРІ Ц. М.

ЕЛОВААРА Я ЛАХТІНЕН M.

Мета роботи. Стаття продовжує дослідження авторів, присвячені перехідним процесам в трифазних n'ятистрижневих трансформаторах. Головна мета роботи - запропонувати методику розрахунку параметрів моделі, щчо охоплюють роботу трансформатора з насиченим осердям. Ця мета досягається шляхом використанням кониепиії оберненості моделі.

Методи дослідження. Розрахунок параметрів моделі виконується з використанням магнітної схеми замімення трансформатора і побудований на юдеї ї̈ оберненості. Рішення знаходиться шляхом прирівнювання вхідних магнітних опорів, розрахованих з боку внутрішньої $і$ зовнішньої обмоток, і магнітних опорів циих обмо- 
ток у повітрі.

Отримані результати. Точність моделювання процесів в присутності ГІТ перевищує точність відомих моделей трифазних п'ятистрижневих трансформаторів. Адекватність моделі підтверджується близькістю прогнозованих фазних струмів і спожсиваної реактивної потужності, до відповідних величин, виміряним в експерименті на двох 400 МВА трансформаторах, які були під’єднані до енергосистеми напругою 410 кВ. Обгрунтованість моделі перевірена при постійних струмах в нейтралі силою 75 і 200 А. Показано застосовність моделі для оцінки кидків струму включення.

Наукова новизна. Оригінальність і новизна методу полягає в можливості визначати параметри моделі без використання експериментальних даних, що отримані при насиченому осерді. Метод забезпечує оберненість моделі триобмоточного трансформатора, тобто ї̈ коректну поведінку при збудженні будь якої з обмоток.

Практична иінність. Практична чінність $і$ значимість статті обумовлені тим, що запропонована модель трансформатора являє собою простий і надійний інструмент для дослідження електричних систем. В якості практично важливого результату, показано правильне прогнозування моделлю часового відгуку трансформатора, що спостерігався в експерименті.

Ключові слова: n'ятистрижневий трансформатор; топологічна модель; оборотна модель; перехідний прочес; форми струмів; експеримент; геомагнітно-індуковані струми; струми включення.

\section{ТОПОЛОГИЧЕСКАЯ ОБРАТИМАЯ МОДЕЛЬ ТРЕХФАЗНОГО ПЯТИСТЕРЖНЕВОГО ТРАНСФОРМАТОРА}

ЗИРКА С. Е.

д-р техн. наук, профессор кафедры систем автоматизированного управления Днепровского национального университета, Днепр, Украина, e-mail: zirka@email.dp.ua

МОРОЗ Ю. И. канд. техн. наук, доцент кафедры систем автоматизированного управления Днепровского национального университета, Днепр, Украина, e-mail: yuriy_moroz@i.ua

АРТУРИ Ц. М. профессор факультета электроники, информации и биоинженерии Миланского Политехнического института, Милан, Италия, e-mail: cesaremario.arturi@polimi.it;

ЭЛОВААРА Я. д-р техн. наук, Fingrid Оуј, Хельсинки, Финляндия, e-mail: jarmo.elovaara@fingrid.fi;

ЛАХТИНЕН М. д-р техн. наук, Fingrid Оуј, Хельсинки, Финляндия, e-mail: matti.2.lahtinen@gmail.com.

Цель работы. Статья продолжает исследования авторов, посвященные переходным прочессам в трехфазных пятистержневых трансформаторах. Главная иель работь - предложить методику расчета параметров модели, охватывающих работу трансформатора с насыщенным сердечником. Эта цель достигается использованием концепции обратимости модели.

Методы исследования. Расчет параметров модели выполняется с использованием магнитной схемь замещения трансформатора и основан на идее ее обратимости. Решение находится путем приравнивания входных магнитных сопротивлений, определяемых со стороны внутренней и внешней обмоток, и магнитных сопротивлений этих обмоток на воздухе.

Полученные результаты. Точность моделирования проиессов при наличии ГИТ превышает точность известных моделей трехфазных пятистержневых трансформаторов. Адекватность модели подтверждается близостью предсказанных фазных токов и потребляемой реактивной мощности, к соответствующим величинам, измененным в эксперименте на двух 400 МВА трансформаторах, подключенных $к$ энергосистеме с напряжением 410 кB. Обоснованность модели проверена при постоянных токах в нейтрали силой 75 и $200 \mathrm{~A}$. Показана применимость модели для оченки бросков тока включения.

Научная новизна. Оригинальность и новизна предложенного метода состоит в возможности определять параметры модели без использования экспериментальных данных, полученных при насыщенном сердечнике. Метод обеспечивает обратимость модели трехобмоточного трансформатора, то есть ее правильное поведение при возбуждении любой обмотки устройства.

Практическая ченность. Практическая ценность и значение статьи обусловлено тем, что предложенная модель трансформатора является простым и надежным инструментом для исследования электрических сетей. В качестве практически важного результата, показано правильное предсказание моделью временного отклика трансформатора, наблюдаемого в эксперименте.

Ключевые слова: пятистержневой трансформатор; топологическая модель; обратимая модель; переходный процесс; форма токов; эксперимент; геомагнитно индуцированные токи; токи включения. 